\title{
Movements and foraging of predators associated with mesophotic coral reefs and their potential for linking ecological habitats
}

\author{
Yannis P. Papastamatiou ${ }^{1,2, *}$, Carl G. Meyer ${ }^{3}$, Randall K. Kosaki ${ }^{4}$, \\ Natalie J. Wallsgrove ${ }^{5}$, Brian N. Popp ${ }^{5}$ \\ ${ }^{1}$ Scottish Oceans Institute, School of Biology, University of St. Andrews, St. Andrews, Fife KY16 8LB, UK \\ ${ }^{2}$ Florida Museum of Natural History, University of Florida, Gainesville, FL 32611, USA \\ ${ }^{3}$ Hawaii Institute of Marine Biology, University of Hawaii at Manoa, Kaneohe, HI 96744, USA \\ ${ }^{4}$ NOAA NOS Papahānaumokuākea Marine National Monument, Honolulu, HI 96818, USA \\ ${ }^{5}$ Department of Geology and Geophysics, University of Hawaii at Manoa, Honolulu, HI 96822, USA
}

\begin{abstract}
Marine predators will often perform diel and seasonal movements associated with specific habitats. In tropical areas, mesophotic coral reefs may be an important habitat type for many predators, but their use of these areas has rarely been investigated. We used results of acoustic telemetry and stable isotope analyses to investigate the diel and seasonal movements of Galapagos sharks Carcharhinus galapagensis and giant trevally Caranx ignobilis captured from a mesophotic reef (depth: 50 to $70 \mathrm{~m}$ ) at an uninhabited Pacific atoll. All predators associated with mesophotic reefs performed horizontal and vertical movements over seasonal and diel time frames. Galapagos sharks performed reverse diel vertical movements, diving deeper during the night than during the day, while giant trevally displayed a mix, with some individuals performing regular diel movements (deep during the day, shallow at night) and others performing reverse vertical diel movements. Trevally used very shallow water during the summer spawning periods. The isotopic compositions of predators suggest they primarily forage in shallow reefs, although approximately $35 \%$ of resources came from mesophotic reefs. Similar to their variability in vertical movement strategies, giant trevally occupied a wide range of trophic positions, potentially due to individual specialization in diet and high levels of intra-specific competition. Mesophotic reefs may provide some prey to upper level predators but also serve as a refuge habitat. The frequent movements between habitats suggest that marine predators may function as significant transporters of nutrients, particularly from shallow to mesophotic reefs.
\end{abstract}

KEY WORDS: Acoustic telemetry - Galapagos sharks · Giant trevally · Network analysis · Amino acids $\cdot$ Stable isotopes $\cdot$ Trophic ecology

\section{INTRODUCTION}

Marine animals often demonstrate cyclical patterns of habitat use over diel, tidal and seasonal time frames. These movements may consist of horizontal movements to and from a 'core area', vertical movements throughout the water column, or both (e.g.

\footnotetext{
${ }^{*}$ Corresponding author: ypapastamatiou@gmail.com
}

Klimley \& Nelson 1984, Chapman et al. 2007, Meyer et al. 2007). Regular diel vertical movements often consist of fishes using deeper habitats during daytime and shallower habitats at night, although there are many cases where the reverse behavior is seen (Sims et al. 2005, 2006, Chapman et al. 2007, Andrews et al. 2009). The function of diel horizontal

() The authors 2015. Open Access under Creative Commons by Attribution Licence. Use, distribution and reproduction are unrestricted. Authors and original publication must be credited. 
and vertical movements is still not fully resolved but may include predator avoidance, tracking of prey movements or behavioral thermoregulation (Sims et al. 2005, 2006, Andrews et al. 2009).

Animal movements between habitats may result in nutrient transport from high to low productivity areas, which can represent a significant contribution to ecosystem nutrient cycling (Lundberg \& Moberg 2003, Schmitz et al. 2010). Predators can directly influence nutrient cycling by consuming prey in one habitat, and excreting or egesting in others (Schmitz et al. 2010). Nutrient transfer has been demonstrated for planktivorous and herbivorous fishes but far less is known for large, reef-associated carnivores, despite the longer range movements performed by these animals potentially linking distant habitats (Geesey et al. 1984, Meyer \& Schultz 1985, Matich et al. 2011, McCauley et al. 2012, Ketchum et al. 2014). For example, diver observations and stable isotopes suggest that grey reef sharks at a Pacific atoll may be refuging and foraging in different habitats (McCauley et al. 2012). These dynamics may be particularly important for predators making regular and periodic movements between habitats, both individually and aggregated or schooling (Schmitz et al. 2010).

Mesophotic coral ecosystems (MCEs) occur at approximate depths of 50 to $130 \mathrm{~m}$ in tropical and subtropical locations (Kahng et al. 2014). Recent studies have shown that MCEs can contain a high diversity of invertebrates and fishes, and may provide important links to shallower habitats through the export or import of nutrients and/or larvae (e.g. Bongaerts et al. 2010, Slattery et al. 2011, Kane et al. 2014). Reefassociated sharks are known to use vertical habitat that includes the range of MCEs (i.e. 100s of meters), although their specific association with these reefs has not been measured (e.g. Chapman et al. 2007, Meyer et al. 2010). Due to their deeper location, fishing pressure may be lower on MCEs and could potentially provide fishes with refuge habitat (the 'refuge in depth' hypothesis, Chapman et al. 2007, Bongaerts et al. 2010). However, there are virtually no data on movements of fishes between shallow habitats and MCEs to properly address this hypothesis (e.g. Slattery et al. 2011). The possibility that mobile animals could transfer nutrients between shallow reefs and MCEs has already been raised, but to the best of our knowledge no study has attempted to quantify this process (Slattery et al. 2011). In order to determine the direction of nutrient transfer, we need to be able to clearly differentiate foraging and refuging habitats.
A combination of telemetry and stable isotope analysis can allow physical movements of animals to be correlated with potential locations of foraging (e.g. Papastamatiou et al. 2010, Carlisle et al. 2012). The $\delta^{15} \mathrm{~N}$ and $\delta^{13} \mathrm{C}$ values in an animal's tissue can provide information on their trophic position and foraging location. Briefly, $\delta^{15} \mathrm{~N}$ values can reflect an animal's trophic position, while $\delta^{13} \mathrm{C}$ values typically record the source of carbon on which they feed. Importantly, both $\delta^{15} \mathrm{~N}$ and $\delta^{13} \mathrm{C}$ values vary in relation to the isotopic composition of the primary producers at the base of the food chain from which the predator feeds (e.g. Post 2002). However, the spatial resolution of isotope analysis is such that feeding locations can generally only be resolved over large spatial scales and are unsuitable for studies at the diel scale (Carlisle et al. 2012). A recent study of the shallow reefs of the remote Northwestern Hawaiian Islands (NWHI) suggested that the major carbon source for shallow reef food webs came from benthic algae (Hilting et al. 2013). However, there are generally higher abundances of planktivorous fishes on MCEs, with lower numbers of herbivores, particularly in Hawaii (Slattery et al. 2011, Kahng et al. 2014, Kane et al. 2014). This suggests that phytoplankton is a more important carbon source on Hawaiian MCEs and that it is possible to resolve predator foraging on shallow versus MCE habitats. The goal of our study was to use acoustic telemetry to quantify horizontal and vertical movements of marine predators (sharks and teleosts) at an MCE surrounding an uninhabited Hawaiian atoll. We then used the carbon and nitrogen isotopic compositions of these predators to infer foraging habitats and evaluate the direction of nutrient transfer.

\section{MATERIALS AND METHODS}

\section{Study site}

Pearl and Hermes Atoll (P\&H) is an uninhabited atoll located towards the northern end of the NWHI chain, and is part of the Papahānaumokuākea Marine National Monument, one of the world's largest Marine Protected Areas (27.9 $\mathrm{N}, 175.9^{\circ} \mathrm{W}$, Fig. 1). As such, it has remained unfished for over $14 \mathrm{yr}$, and has large numbers of predators, particularly sharks and trevally (Sudekum et al. 1991, Papastamatiou et al. 2006). The south coastline consists of spur and groove or flat rock habitat down to depths of $30 \mathrm{~m}$ (see Meyer et al. 2007 for further details), followed by a gradual increase in depth until the MCEs are 


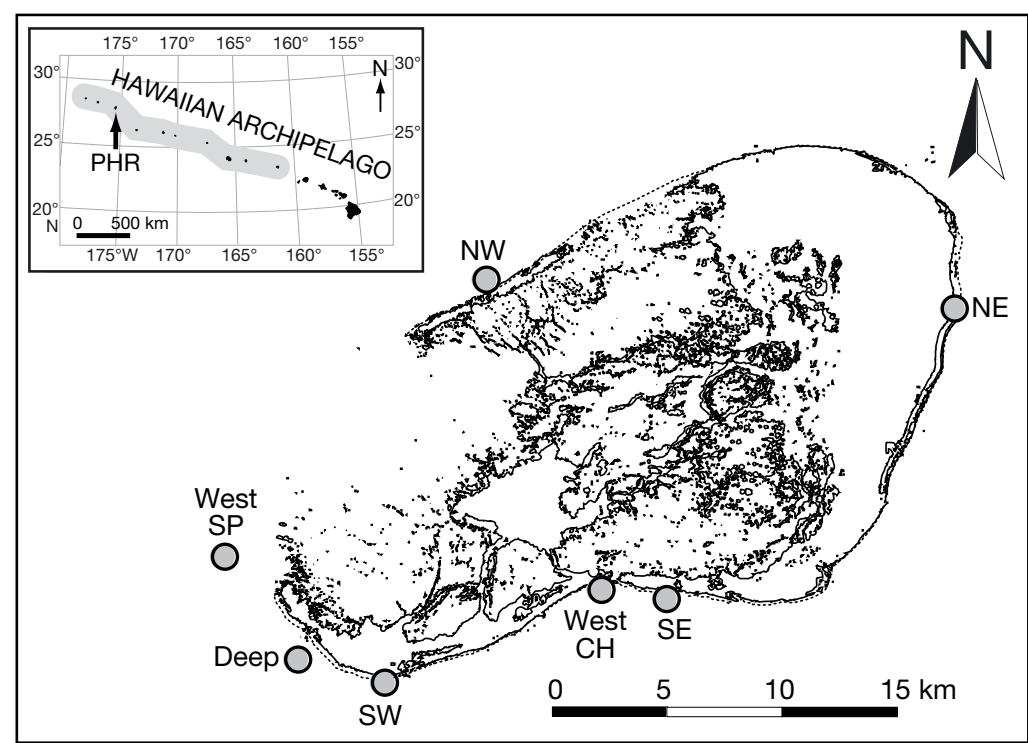

Fig. 1. Location of Pearl and Hermes Atoll (P\&H) within the Northwestern Hawaiian Islands and locations of VR2W receivers. Abbreviations: Deep (mesophotic reef), West SP (Spur and Groove) and West $\mathrm{CH}$ (Channel) receivers

reached approximately $1 \mathrm{~km}$ from shore (Fig. 1). The top of the MCE is approximately $55 \mathrm{~m}$ deep, with a steep ledge dropping to $65-70 \mathrm{~m}$.

\section{Tagging and sampling}

We visited $\mathrm{P} \& \mathrm{H}$ during 2 cruises in the summers of 2011 and 2012, where we caught Galapagos sharks Carcharhinus galapagensis and giant trevally Caranx ignobilis using baited hand-lines over the MCE at the SW corner of the atoll. Predators were restrained along the side of the boat, measured (total length, TL) and sexed (sharks). A Miltex $8 \mathrm{~mm}$ biopsy corer was used to remove a small plug (approximately $1 \mathrm{~g}$ ) of white muscle along the flank of the animal. For a proportion of animals, we then made a 2 to $3 \mathrm{~cm}$ incision along the ventral surface, implanted a V16 acoustic transmitter $(69 \mathrm{kHz}, \mathrm{Vemco})$ into the body cavity and closed the incision using a single suture. Ten fish (5 giant trevally, 5 Galapagos sharks) were tagged with V16TP tags which also measure swimming depth and body temperature (maximum depth: $340 \mathrm{~m}$, accuracy $\pm 17 \mathrm{~m}, \pm 0.5^{\circ} \mathrm{C}$ ), while an additional 5 animals (4 giant trevally, 1 Galapagos shark) were tagged with V16 transmitters (i.e. presence/absence only). Transmitters emitted an acoustic pulse train every 30 to $90 \mathrm{~s}$, and had an estimated battery life of $1324 \mathrm{~d}$. Tagged individuals were monitored using an array of 7 underwater listening stations (VR2W, Vemco) deployed throughout the atoll, 6 close to the shallow reefs (depth 10 to $30 \mathrm{~m}$ ) and 1 adjacent to an MCE at $65 \mathrm{~m}$ depth (deep receiver). All receivers were attached to mooring floats and were 1 to $2 \mathrm{~m}$ off the bottom. The difference in the number of receivers in shallow reefs versus MCEs was simply due to the logistics of having to perform technical dives (short bottom time, 1 dive per day, surface support etc.). Divers collected reef fishes for stable isotope analysis using pole spears, on both shallow reefs $(<30 \mathrm{~m})$ and MCEs (55 to $70 \mathrm{~m}$ ).

We determined receiver detection ranges for a small number of shallow reef VR2Ws by towing a V16 test tag behind a boat and slowly drifting up to $1000 \mathrm{~m}$ from the VR2W. A VR100 receiver logged detections of the test tags, which were compared with detections from the VR2W to estimate the distance at which detections ceased (range 500 to $800 \mathrm{~m}$ ). Due to limited time at the atoll on expeditions, we were not able to rigorously range test all receivers under different conditions. For further estimates of performance, we calculated 2 additional metrics of receiver performance using metadata recorded by the VR2Ws: the rejection coefficient and the noise quotient (Simpfendorfer et al. 2008, see Supplement 1 at www.intres.com/articles/suppl/m521p155_supp.pdf).

\section{Presence/absence analysis}

We filtered acoustic data so that at least 2 detections had to occur within $24 \mathrm{~h}$ for 'presence' to be considered valid. Next, we calculated the number of detections at each receiver and the number of days each animal was detected at each receiver. We compared the amount of time spent at receivers by Galapagos sharks and giant trevally, using the percentage number of days (out of the year monitoring period) each predator was detected on each receiver. The percentage number of days was square-root transformed to meet the assumption of homogeneity of variance, a Bray-Curtis similarity matrix was generated, and a 1-way ANOSIM test with 999 random permutations was used to compare habitat overlap between the 2 species. The test quantifies overlap (with the Global R value) and determines if overlap 
(or lack of) is statistically significant. The percentage number of days detected at each receiver was graphically compared using non-metric multidimensional scaling ordinations (nMDS), and SIMPER analysis was used to determine which receivers were driving apparent differences in habitat use. All overlap analysis was performed using Primer (v. 5.2.9).

We investigated periodicity in acoustic detections using Continuous Wavelet Transformations (CWTs). CWTs identify dominant cyclical signals in time series data sets and track how these change throughout the time series (e.g. Riotte-Lambert et al. 2013). Essentially, the CWT searches for any cyclical patterns in acoustic detections at each receiver (e.g. diel or tidal signals). We determined the number of detections that occurred on the deep receiver during every hour of the entire monitoring period, for each individual predator. We then produced CWTs and associated point-wise tests $(95 \%)$ using a Morlet wavelet in the Sowas package (Maraun et al. 2007) in R v.2.9.1 (R Development Core Team 2013). The CWT identifies cyclical patterns in detections, while the point-wise test highlights those that are statistically significant.

We used network analysis to quantify which habitats may be linked by predator movements. Network analysis is traditionally used to quantify relationships between individuals but has recently been applied to animal movement data (Jacoby et al. 2012). The network consists of a series of nodes (receivers) that are linked by edges (i.e. an individual detected moving from one receiver to another). We calculated 2 metrics for each individual at each receiver: degree centrality, which is a measure of the number of connections going into or out of a node, and betweenness, which is a measure of how often a node acts as a bridge between 2 other nodes (Hanneman \& Riddle 2005, Jacoby et al. 2012). We also calculated Taylor dyadic influence scores for sharks and trevally, which compare interactions between nodes to determine if the exchange of information is symmetrical or asymmetrical (i.e. Are there equal numbers of movements into and out of 1 node? Hanneman \& Riddle 2005). The networks are biased by the placement of receivers but provide insight into how the animals move between areas. We performed network analysis on all data combined, but were specifically interested in movements that could transfer nutrients between habitats. Lemon sharks Negaprion brevirostris have been observed to continue fecal production for up to $110 \mathrm{~h}$ after feeding (Wetherbee \& Gruber 1990). We therefore set a filter so that only movements that occurred within $110 \mathrm{~h}$ were considered in the net- works. All network analysis was conducted using SOCPROG, a MATLAB-based program (Whitehead 2009), and UCINET v. 6.391 (Analytic Technologies).

\section{Vertical movements and body temperature}

Telemetry sensor data (depth and temperature) are not independent, and residuals may be strongly autocorrelated, making the use of conventional parametric statistics problematic. Furthermore, the time intervals between data points are not evenly spaced. To address the relative importance of a diel cycle (h) and time of year (mo) on depth and body temperature of predators, we built generalized additive models (GAM) with a Gaussian error distribution, which have the advantage of permitting the pattern of temporal autocorrelation to be added to the model explicitly. We modeled the serial correlation in our data using a continuous auto-regressive process of order 1 (AR1) with time as the position variable. The continuous AR1 specification accounts for the unequal temporal spacing common in opportunistically collected time series telemetry data by calculating the magnitude of serial dependence as a function of continuous distance between time steps. The most parsimonious models were selected using corrected Akaike's information criteria (AIC), Bayesian's information criteria (BIC) and likelihood ratios. Models were fit using restricted maximum likelihood with the mgcv function in the nlme library of $\mathrm{R}$ (Wood 2006). The analysis ensured that diel changes in depth and body temperature were real and not an artifact of seasonal changes in habitat use (i.e. it compares diel changes in depth/temperature within months and does not combine them together throughout the year). We also confirmed patterns visually by graphically examining diel changes in depth and temperature within specific seasons.

\section{Stable isotope analysis}

Bulk tissue analysis

Predator and reef fish muscle samples were dried at $60^{\circ} \mathrm{C}$ and ground into a fine powder. All elasmobranchs retain urea in their tissue, which may bias measures of $\delta^{15} \mathrm{~N}$ values, so urea was extracted from all shark samples with distilled water (Kim \& Koch 2012). Experimental studies with sharks have shown that this method removes urea without influencing muscle protein isotopic composition (Kim \& Koch 
2012). Shark and reef fish C:N ratios suggested low tissue lipid content $(<3.5 \mathrm{~mol} / \mathrm{mol})$ so no lipid extraction was conducted. However, giant trevally had C:N ratios approaching 4.0, indicating higher lipid content which may bias carbon isotope results (Fry et al. 2003). In order to be certain that we were comparing the isotopic composition of protein between sharks and trevally, we conservatively decided to extract lipids from all trevally tissues. Lipid extraction will not influence $\delta^{15} \mathrm{~N}$ values but will have a small effect on $\delta^{13} \mathrm{C}$ (approximately $0.1 \%$, Fry et al. 2003). More importantly, lipid extraction produced trevally C:N ratios similar to sharks, allowing for more appropriate comparisons between these species. The $\delta^{13} \mathrm{C}$ and $\delta^{15} \mathrm{~N}$ values were determined using an isotope mass spectrometer (Delta ${ }^{\text {Plus } X P) ~ c o u p l e d ~ w i t h ~ a ~ c a r-~}$ bon-nitrogen analyzer (Costech ECS 4010/ConFlo IV). $\delta$ values are reported as \%o relative to Vienna PeeDee Belemnite (VPDB) for $\mathrm{C}$ and atmospheric $\mathrm{N}_{2}$ for N. Measurement accuracy was determined using glycine samples with well characterized \% C, \% N, $\delta^{15} \mathrm{~N}$ and $\delta{ }^{13} \mathrm{C}$ values, with an overall error $< \pm 0.1 \%$.

We constructed a series of generalized linear models (GLMs) to investigate the influence of predator species and size on bulk tissue $\delta^{15} \mathrm{~N}$ and $\delta^{13} \mathrm{C}$ values. In each case, the isotopic composition was set as the dependent variable, and predator TL was set as covariate. We also generated an interaction term between species and TL. We used a Bayesian mixing model, which also incorporates uncertainty in predator and prey isotope and fractionation values, to determine if predators at P\&H were foraging on MCEs (Moore \& Semmens 2008). Stomach content analysis of giant trevally and Galapagos sharks in the NWHI suggests they consume a wide range of reef fishes, so we included isotopic results for several guilds including planktivores, zooplanktivores, herbivores, and carnivores (Sudekum et al. 1991, Papastamatiou et al. 2006). These included species that have previously been identified in stomach contents as well as potential prey items that were abundant on the reefs. We calculated prey stable isotope signatures for MCEs and shallow reefs using a random effects meta-analysis in MetaWin (e.g. Carlisle et al. 2012). The metaanalysis calculates habitat-specific isotope values by weighing species means by the inverse of their variance and between-sample variance. We used MixSir, a MATLAB-based program, to generate mixing models with 1 million iterations (Moore \& Semmens 2008). We used diet-tissue discrimination factors (DTDF) of $2.43 \pm 0.27 \%$ ond $0.86 \pm 0.28 \%$ (for $\delta^{15} \mathrm{~N}$ and $\delta^{13} \mathrm{C}$, respectively) for sharks (Hussey et al. 2010). For trevally, we calculated $\delta^{15} \mathrm{~N}$ - and $\delta^{13} \mathrm{C}$-specific DTDFs using the equation for fish published by Caut et al. (2009) (DTDF $\delta^{15} \mathrm{~N}=2.85 \pm 0.17 \%$ o, $\delta^{13} \mathrm{C}=0.19 \pm$ $0.25 \%$ ). As a sensitivity analysis, we also ran the mixing models using a variety of published tissue discrimination factors (for both sharks and teleosts) and using arithmetically lipid-corrected shark bulk isotope values (see Supplement 10).

\section{Compound specific amino acid isotopes}

We were interested in the ecological role of predators on MCEs, in particular their trophic position (TP). Calculating TP from bulk tissue nitrogen isotopic compositions can be complicated by the fact that these bulk isotope values vary based on where the animal is foraging (Post 2002). Compound-specific isotope analysis of amino acids (AA-CSIA) avoids many of the shortcomings of traditional bulk tissue isotope analysis. In samples of consumer tissues, 'source' amino acids (e.g. phenylalanine [Phe]) appear to retain the isotopic composition of the nitrogen (N) sources at the base of the food web, whereas in predatory fishes, 'trophic' amino acids (e.g. glutamic acid [Glu]) become ${ }^{15} \mathrm{~N}$ enriched relative to source amino acids by about $~ 5.9 \%$ per trophic level (Popp et al. 2007, Dale et al. 2011, Hannides et al. 2013, Lorrain et al. in press). One key advantage of this technique is that predator tissue alone is sufficient for estimating TP. There is a constant difference in $\delta^{15} \mathrm{~N}$ between glutamic acid and phenylalanine for primary producers of $3.4 \pm 0.9 \%$ (Chikaraishi et al. 2009). We carried out AA-CSIA of predator tissues and 4 milletseed butterfly fish Chaetodon milliaris collected on the mesophotic reefs. Dive surveys confirm that zooplanktivores are the most abundant trophic group on Hawaiian MCEs, and of those, $C$. milliaris is one of the most abundant (Kane et al. 2014; see Supplement 11). We selected C. milliaris as a representative MCE zooplanktivore to compare against isotope values from larger predators (see McCauley et al. 2012). Muscle tissues were subjected to acid hydrolysis, esterification of the carboxyl terminus and trifluoracetylation of the amine group (Popp et al. 2007, Dale et al. 2011). Prior to AA-CSIA, samples were evaporated to dryness, re-dissolved in 100 to $1000 \mu \mathrm{l}$ ethyl acetate and analyzed within $24 \mathrm{~h}$. The $\delta^{15} \mathrm{~N}$ values of individual amino acids were measured using isotope ratio monitoring gas chromatography-mass spectrometry (Delta V Plus/Trace GC/GC-C III Interface) using methods described by Dale et al. (2011) and Hannides et al. (2013). All samples were analyzed at least in triplicate, and uncer- 
tainty in the accuracy of the nitrogen isotope analysis of amino acids was determined by analysis of norleucine and amino adipic acid with known $\delta^{15} \mathrm{~N}$ values co-injected with every sample. More specifically, the uncertainty in the accuracy of the isotopic analysis was determined using the known $\delta^{15} \mathrm{~N}$ value for norleucine to determine a measured $\delta^{15} \mathrm{~N}$ value of amino adipic acid, treating it as an unknown. Uncertainty in the accuracy of isotopic values of these internal reference amino acids co-injected with samples averaged $\pm 0.4 \%$ o $(0.1$ to $0.8 \%$, 1 standard deviation based on at least triplicate analysis of these compounds in each sample).

We used the results of AA-CSIA to calculate the TP of each predator using the modified equation:

$$
\mathrm{TP}_{\mathrm{Glu} / \mathrm{Phe}}=\frac{\left(\delta^{15} \mathrm{~N}_{\mathrm{Glu}}-\delta^{15} \mathrm{~N}_{\mathrm{Phe}}\right)-3.4}{5.9}+1
$$

where $\mathrm{TP}_{\mathrm{Glu}}$ /Phe is the TP determined from the measured $\delta^{15} \mathrm{~N}$ values of Glu and Phe, $3.4 \pm 0.9$ is the isotopic difference between $\delta^{15} \mathrm{~N}$ values of glutamic acid and phenylalanine in the primary producers (Chikaraishi et al. 2009), and $5.9 \pm 1.0$ is the trophic enrichment factor (TEF) estimated for elasmobranchs (Dale et al. 2011). The standard deviation of $\mathrm{TP}_{\mathrm{Gl}} / \mathrm{Phe}$ was determined by propagation of errors using the analytical uncertainty in the $\delta^{15} \mathrm{~N}$ values of glutamic acid and phenylalanine based on replicate analyses at least in triplicate and the uncertainty in the values 3.4 and 5.9 listed above (see Blum et al. 2013). We used a hierarchical agglomerative cluster analysis (Primer 5.2.9) to separate groups of sharks and giant trevally based on their TP, and GLMs to quantify the effects of species and animal size on TP. GLMs were constructed with a Gaussian error distribution in Minitab v.14.

\section{RESULTS}

\section{Presence/absence analysis}

We acoustically tagged 6 Galapagos sharks (TL 165 $\pm 22 \mathrm{~cm}, 3$ males, 3 females) and 9 giant trevally (103 $\pm 8 \mathrm{~cm})$ at $\mathrm{P} \& \mathrm{H}$. We detected 5 Galapagos sharks over durations of 14 to $368 \mathrm{~d}$ (median $334 \mathrm{~d}$, time between release and last detection), and 8 giant trevally over durations of 301 to 366 d (median 365 d) from September 14, 2011 until September 29, 2012. In addition, we detected 5 trevally that were tagged in a separate study by the West Channel (West $\mathrm{CH}$ in Fig. 1) in shallow water during field work in the summer of 2010. VR2W performance analysis suggested that receivers performed similarly although there was slightly poorer performance on the deep (MCE) and west spur and groove (West SP) receivers (Supplement 1, Fig. S1). Galapagos sharks were detected on shallow reef receivers for $20 \pm 12 \%$ of days, and on the MCE receiver for $18 \pm 30 \%$ of days throughout the year (Table 1). There was a great deal of individual variability, with only 1 shark detected frequently on the MCE deep receiver (Supplement 2, Table S1, at www.int-res.com/articles/suppl/m521p155_supp. pdf). Giant trevally were detected on shallow reef receivers for $17 \pm 14 \%$ of days and on the $\mathrm{MCE}$ receiver for $23 \pm 19 \%$ of days, throughout the year. There were significant differences in the amount of time Galapagos sharks and giant trevally spent within various areas of the acoustic array (1-way ANOSIM, R = 0.56, $\mathrm{p}=0.02$, Supplement 3, Fig. S2 at www.int-res.com/articles/suppl/m521p155_supp. pdf). The differences between species were primarily explained by trevally spending more time adjacent to the deep (38\% dissimilarity), and the west spur and

Table 1. Network analysis for giant trevally Caranx ignobilis and Galapagos sharks Carcharhinus galapagensis at Pearl and Hermes Atoll. Metrics include outward degree centrality $\left(\mathrm{k}_{\mathrm{i}}{ }^{\text {out }}\right)$, inward degree centrality $\left(\mathrm{k}_{\mathrm{i}}^{\text {in }}\right)$, and Betweenness $\left(\mathrm{B}_{\mathrm{i}}\right)$. The percentage of days detected throughout the monitoring period (1 $\mathrm{yr}_{\text {; }}$ Days detect. [\%]) and percentage detections at each receiver (\% detect.) are given as means ( $\pm 1 \mathrm{SD}$ ). See Fig. 1 for locations of the receivers and definition of abbreviations

\begin{tabular}{|c|c|c|c|c|c|c|c|c|c|c|}
\hline \multirow{2}{*}{ Receiver } & \multicolumn{5}{|c|}{ - Giant trevally } & \multicolumn{5}{|c|}{ - Galapagos sharks } \\
\hline & $\mathrm{k}_{\mathrm{i}}^{\text {out }}$ & $\mathrm{k}_{\mathrm{i}}^{\text {in }}$ & $\mathrm{B}_{\mathrm{i}}$ & $\begin{array}{c}\text { Days } \\
\text { detect. }(\%)\end{array}$ & $\begin{array}{c}\% \\
\text { detect. }\end{array}$ & $\mathrm{k}_{\mathrm{i}}^{\text {out }}$ & $\mathrm{k}_{\mathrm{i}}^{\mathrm{in}}$ & $\mathrm{B}_{\mathrm{i}}$ & $\begin{array}{c}\text { Days } \\
\text { detect. (\%) }\end{array}$ & $\begin{array}{c}\% \\
\text { detect. }\end{array}$ \\
\hline Deep & 30 & 30.8 & 35 & 23 (19) & $57(31)$ & 31.5 & 33.7 & 66.7 & $18(30)$ & $43(36)$ \\
\hline West SP & 25.3 & 25.5 & 27.5 & $10(14)$ & $19(17)$ & 27.2 & 26.1 & 50 & $19(12)$ & $56(36)$ \\
\hline SW & 18.2 & 17.6 & 2.5 & $7(4)$ & $22(23)$ & 8.7 & 7.6 & 0 & $0.7(0.6)$ & $1(2)$ \\
\hline NW & 1.0 & 0.8 & 0 & $0.3(0.4)$ & $3(5)$ & 2.2 & 2.2 & 0 & $0.3(0.5)$ & $0.3(0.7)$ \\
\hline West $\mathrm{CH}$ & 0.6 & 0.4 & 0 & $0.1(0.2)$ & $0.2(0.6)$ & 1.1 & 1.1 & 0 & $0.1(0.3)$ & $0.07(0.2)$ \\
\hline SE & 0.2 & 0.2 & 0 & $0.03(0.1)$ & $0.05(0.13)$ & - & - & - & $0(0)$ & $0(0)$ \\
\hline Mean & 12.6 & 12.6 & 10.8 & & & 14.1 & 14.1 & 23.3 & & \\
\hline $\mathrm{SD}$ & 12.4 & 12.7 & 14.6 & & & 12.8 & 13.3 & 29.1 & & \\
\hline $\mathrm{CV}$ & 99.0 & 101.0 & & & & 90.1 & 94.0 & & & \\
\hline
\end{tabular}


a

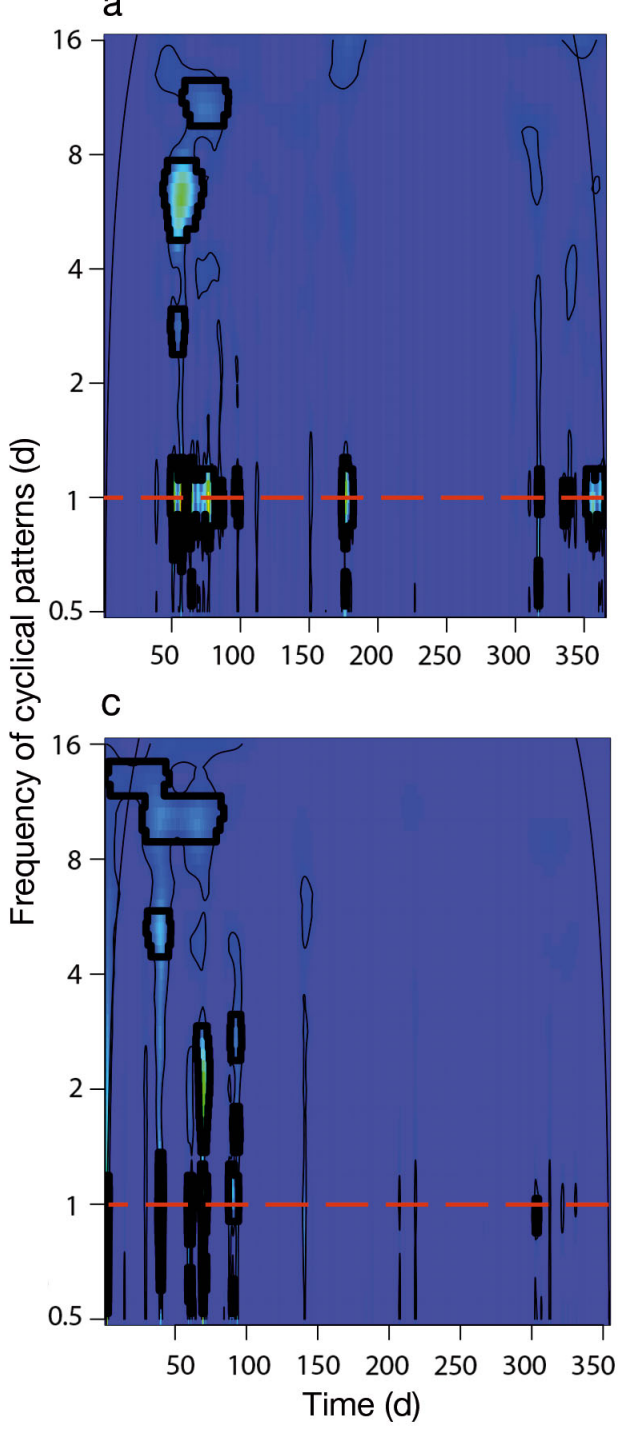

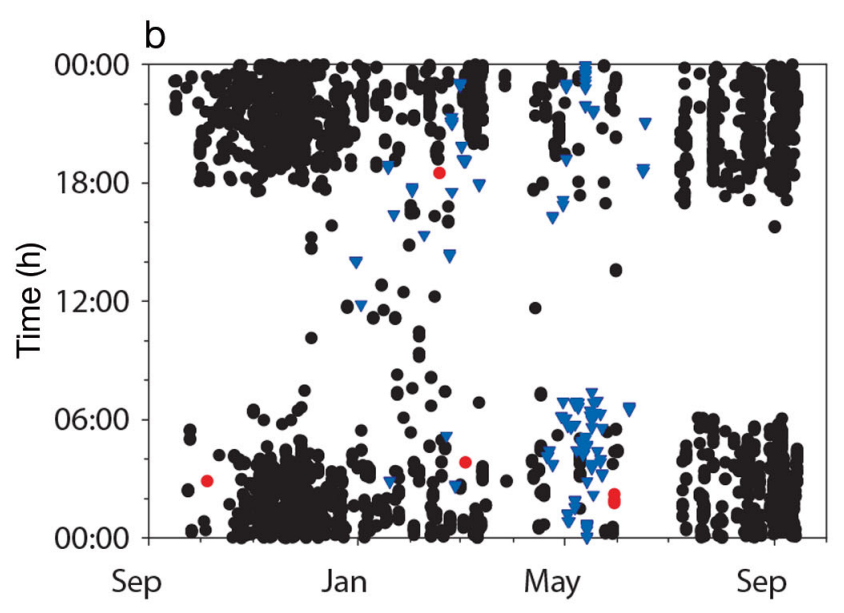
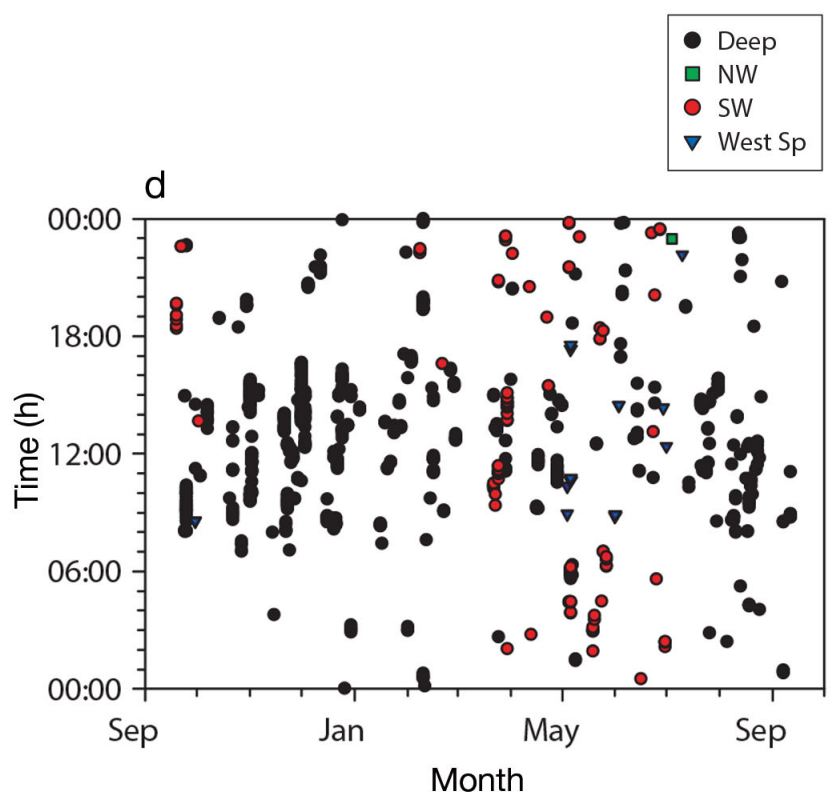

Fig. 2. Continuous wavelet transformations (CWTs) and scatter plots for (a,b) a $199 \mathrm{~cm}$ male Galapagos shark Carcharhinus galapagensis, and (c,d) a $109 \mathrm{~cm}$ giant trevally Caranx ignobilis. CWT $(\mathrm{a}, \mathrm{c})$ identifies cyclical patterns of acoustic detections and how these change throughout the monitoring period. The $x$-axis represents days since tagging (September 2011) and the $y$-axis is frequency of cyclical patterns. Patterns outside the cone of influence should not be considered. Areas circled in black are statistically significant ( $95 \%$ point wise test). The red line highlights the location of $24 \mathrm{~h}$ periodicity in movements. For scatterplots $(b, d)$, each symbol represents a specific acoustic listening station (see Fig. 1)

groove (27\% dissimilarity) receivers. Sharks spent more time adjacent to the SW receiver (24\% dissimilarity, SIMPER).

All predators demonstrated diel patterns of detections at the deep receiver, although diel behavior was not consistent throughout the year (Fig. 2). Galapagos sharks at $\mathrm{P} \& \mathrm{H}$ were all associated with the MCE during night-time periods (between 18:30 $\mathrm{h}$ and 06:30 h), while trevally behavior was more variable, with some individuals present at night and some during the day (Fig. 2). We did not detect sharks continuously, but those individuals detected during the day were primarily detected on shallow reef receivers.
CWT analysis also showed that the majority of trevally demonstrated cyclical patterns of detections with periods of approximately 8 to $12 \mathrm{~d}$ during the month of February (Supplement 4, Fig. S3 at www. int-res.com/articles/suppl/m521p155_supp.pdf).

Network analysis revealed that the MCE is a more important habitat than predicted by frequency of detections alone (Table 1). The deep reef receiver had the highest degree centrality (measure of the relative number of movements into and out of a receiver) and betweenness (measure of how often a receiver acts as a link between other receivers) score for both Galapagos sharks and giant trevally (Table 1). Over- 
all, degree centrality scores were similar for both sharks and trevally, but betweenness was higher in sharks. Taylor's dyadic influence scores for Galapagos sharks showed that movements into and out of the MCE (deep) receiver were symmetrical (Supplement 5, Table S2 at www.int-res.com/articles/suppl/ m521p155_supp.pdf). The scores were more asymmetrical for trevally, suggesting that they enter or exit the MCE via several different routes. When examining networks from filtered data (i.e. potential nutrient transfer), it was clear that the majority of movements for both sharks and trevally were between the MCE (Deep) receiver and either the west spur and groove or the SW receivers (Fig. 3). Giant trevally tagged in 2010 adjacent to shallow reefs visited the MCE receiver but the node had much lower centrality and betweenness scores (Supplement 6, Fig. S4, Table S3 at www.int-res.com/articles/suppl/ m521p155_supp.pdf).

\section{Vertical movements and body temperature}

In all cases, the model that included diel period and season with serial autocorrelation provided the best fit to the data, lowering AIC and BIC scores, and maximizing likelihood ratios. Galapagos sharks occupied deeper depths at night and moved into shallow water during the day (Fig. 4, Table 2). Vertical movements at night included deep dives to the bottom of the MCE, but only $20 \pm 15 \%$ were deeper than $60 \mathrm{~m}$. Diving behavior was associated with some diel change in body temperature, with sharks generally having cooler body temperatures at night, although this was not significant for G2 (Fig. 4, Table 2). Seasonally, Galapagos sharks were detected in shallower water from March to July ( $p$ ranges from $<0.00001$ to 0.05 ), and deeper water from October to December $(p=$ 0.007 to 0.04 , Supplement 7 , Fig. S5 at www.intres.com/articles/suppl/m521p155_supp.pdf). Galapagos sharks had the coolest body temperatures from February to March $\left(20\right.$ to $22^{\circ} \mathrm{C}$ ), and significantly warmer temperatures from May to December (24 to $27^{\circ} \mathrm{C}, \mathrm{p}<0.00001$, Table 2; Supplement 7, Fig. S6).

With the exception of U4, all trevally showed diel changes in depth, although the patterns varied by individual (Fig. 5, Table 2). Fish U3 showed diving behavior very similar to Galapagos sharks, with $20 \%$ of dives to $>60 \mathrm{~m}$ during the night and moving up into shallow water during the day (Fig. 5c,d). Alternatively, U1 occupied deeper depths during the day (but rarely went deeper than $30 \mathrm{~m}$ ), and moved into shallower water at night (Fig. 5a,b). Overall, only $9 \pm$
$20 \%$ of detected dives were deeper than $60 \mathrm{~m}$. When correcting for the effect of season, all trevally showed some diel changes in body temperature, although again the patterns varied in relation to swimming depths (Fig. 5, Table 2). There were consistent seasonal changes in swimming depth and body temperature with trevally detected using shallower depths in May to June $(p<0.00001)$, and warmest body temperatures in May to December $\left(24\right.$ to $28^{\circ} \mathrm{C}$, $\mathrm{p}<0.00001$, Fig. 6, Supplement 8, Fig. S7 at www. int-res.com/articles/suppl/m521p155_supp.pdf). The lowest body temperatures were from February to March (minimum $21^{\circ} \mathrm{C}$, Supplement 8, Fig. S7).

\section{Stable isotopes}

We determined the isotopic composition of bulk muscle tissue from 12 Galapagos sharks $(162 \pm 22 \mathrm{~cm}$ : 4 males, 8 females) and 25 giant trevally $(98 \pm 11 \mathrm{~cm})$. We collected 48 reef fishes (4 species) from shallow reefs and 21 (4 species) from MCEs. Based on the MetaWin analysis, shallow and MCE prey fishes had similar $\delta^{15} \mathrm{~N}$ values (shallow: $7.94 \pm 2.89$; MCE: $7.57 \pm$ 2.93) but MCE species tended to have lower $\delta^{13} \mathrm{C}$ values (shallow: $-15.51 \pm 4.04$; MCE: $-18.65 \pm 4.60$ [Supplement 9, Fig. S8 at www.int-res.com/articles/suppl/ m521p155_supp.pdf]). GLMs revealed a significant influence of species $(F=8.82, \mathrm{p}=0.006)$, TL $(F=6.04$, $\mathrm{p}=0.019)$ and an interaction term between TL and species $(F=7.39, \mathrm{p}=0.01)$ on $\delta^{15} \mathrm{~N}$ values. When analyzed separately, Galapagos sharks were enriched in ${ }^{15} \mathrm{~N}$ relative to giant trevally $\left(\delta^{15} \mathrm{~N}=11.5 \pm 0.3 \%\right.$ and $10.8 \pm 0.6 \%$, respectively). However, while size had a moderate influence on $\delta^{15} \mathrm{~N}$ values of giant trevally $\left(t=2.67, \mathrm{p}=0.014, \mathrm{r}^{2}=0.2\right)$, it had no effect on the values for Galapagos sharks $(t=-0.43, \mathrm{p}=0.68)$. The GLM revealed no influence of species $(F=0.14, \mathrm{p}=$ $0.71)$ or TL $(F=2.43, \mathrm{p}=0.13)$ on $\delta^{13} \mathrm{C}$ values.

The results of the mixing model suggest that Galapagos sharks obtain the majority of their carbon from shallow reefs (median 67\%, 47 to $86 \%$ [95\% CI]) with a smaller contribution from MCEs (median $33 \%, 14$ to $53 \%$ ). Giant trevally also obtained more carbon from shallow reefs (median $60 \%, 48$ to $72 \%$ ), versus $40 \%$ (28 to $52 \%$ ) from MCEs (Fig. 7 ). The use of different discrimination factors did cause some difference in mixing model results, particularly for trevally (Supplement 10, Table S4 at www.int-res. com/articles/suppl/m521p155_supp.pdf). However, the overall result was always the same, with a greater proportion of prey taken from the shallow reef and a larger percentage contribution of shallow reef prey 

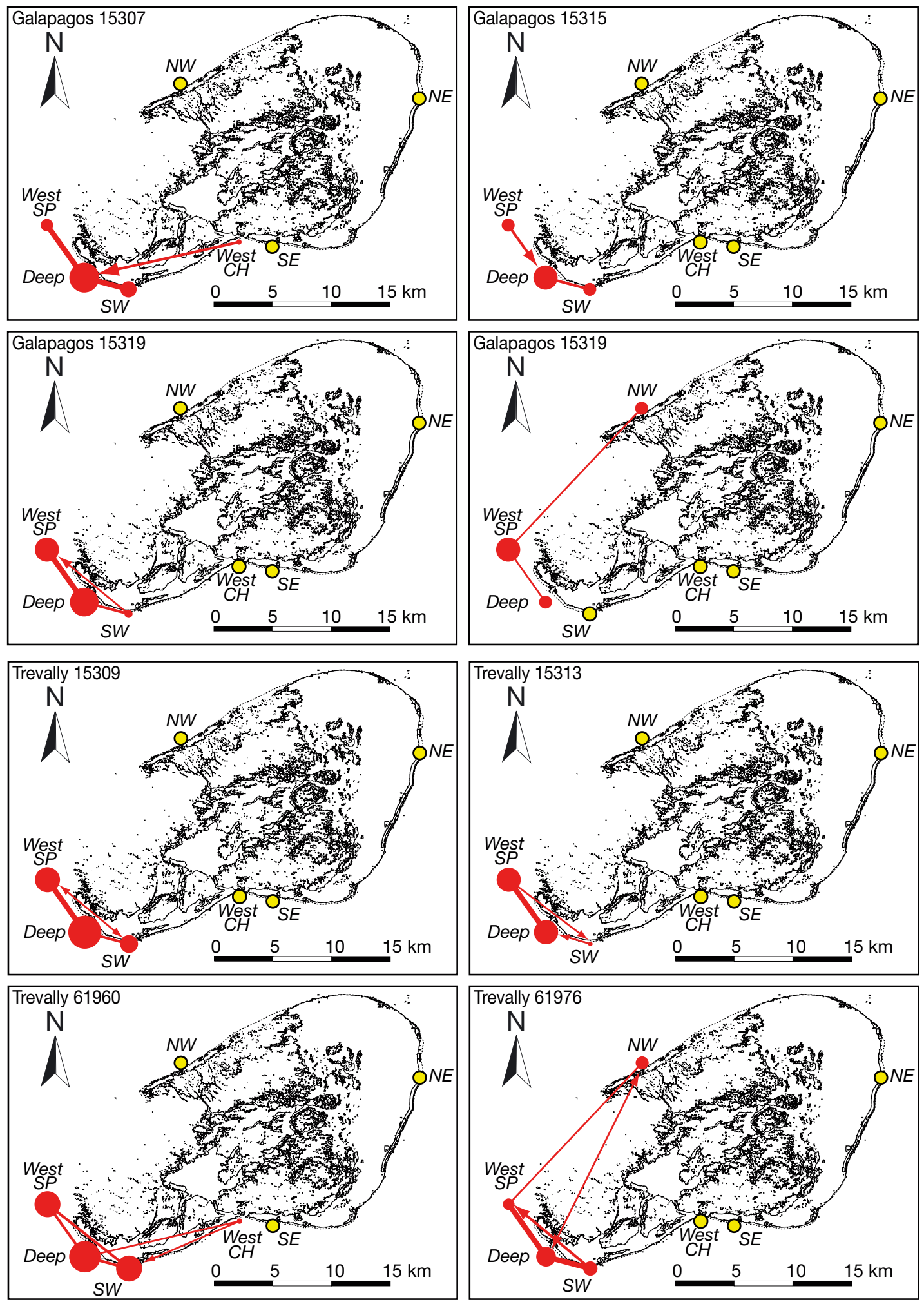

Fig. 3. Network diagrams of individual Galapagos shark (Carcharhinus galapagensis) and giant trevally (Caranx ignobilis) movements at Pearl and Hermes Atoll. Each node represents an acoustic receiver and the size of the node is proportional to centrality. Edge thickness is proportional to the actual number of movements that occurred between nodes. Networks only include movements that occurred within $110 \mathrm{~h}$ and represent potential nutrient transfer between habitats. Yellow nodes represent receivers where there were no detected movements. See Fig. 1 for the definition of abbreviations 

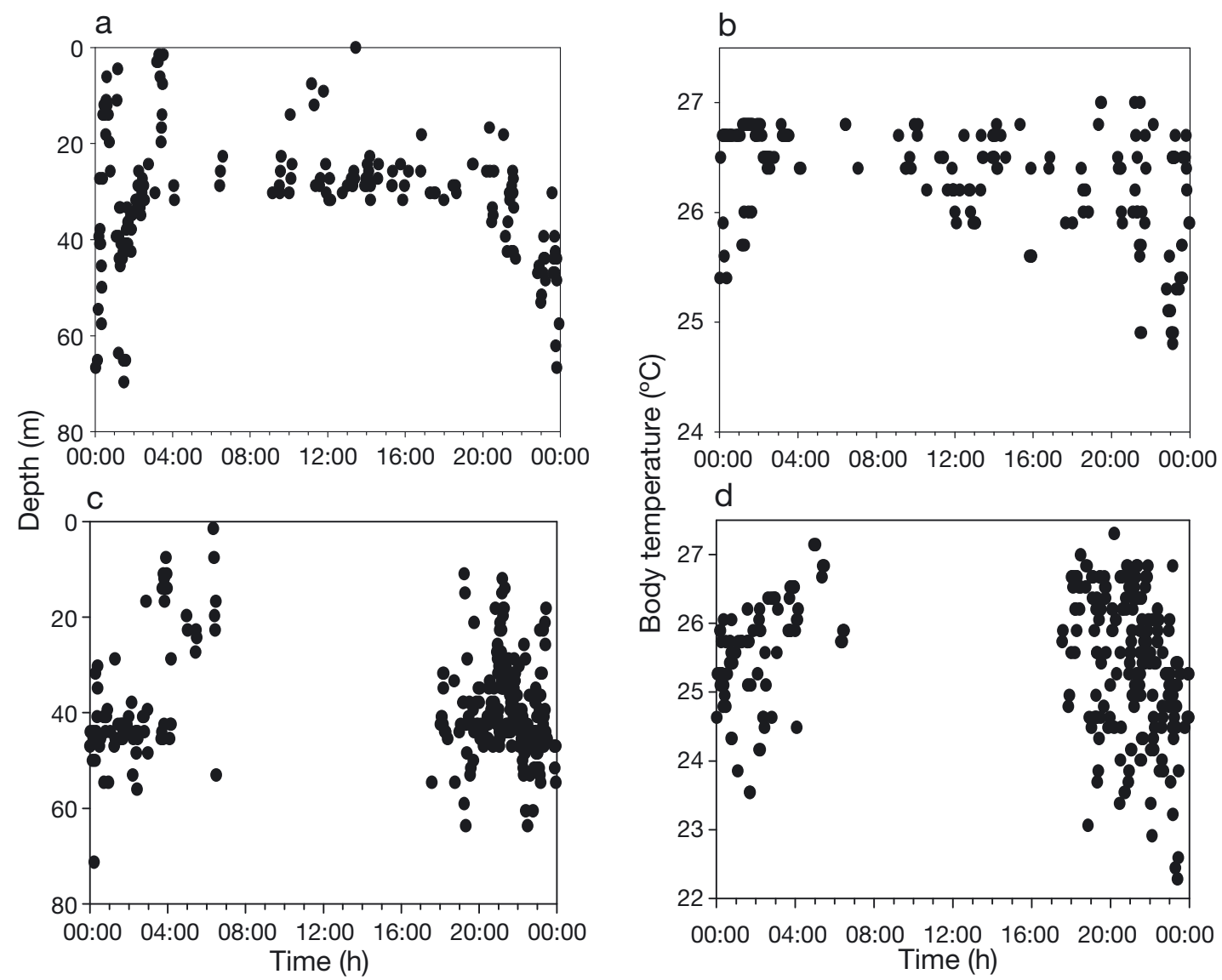

Fig. 4. Diel changes in swimming depth and body temperature of Galapagos sharks Carcharhinus galapagensis (a,b) G2 and (c,d) G3 at Pearl and Hermes Atoll. Data were obtained using passive acoustic transmitters from September to December.

Gaps in data indicate periods where there were no acoustic detections

to shark diet relative to giant trevally. Arithmetic lipid correction in sharks increased the difference in percentage contribution of shallow prey to their diet (i.e. shallow contribution increased, MCE contribution decreased, Supplement 10, Table S4).

Although bulk tissue $\delta^{15} \mathrm{~N}$ values suggest possible differences in trophic level between sharks and giant trevally, these results do not take into account intraspecific variability at the individual level. Results of AA-CSIA indicated that phenylalanine in sharks $(\mathrm{n}=$ $5, \delta^{15} \mathrm{~N}=-0.45 \pm 0.4 \%$ ) was depleted in ${ }^{15} \mathrm{~N}$ relative to phenylalanine in giant trevally $(\mathrm{n}=14,0.67 \pm$ $1.13 \%$ ). Our estimated TPs for Galapagos sharks ranged from 4.4 to 4.7 , while for giant trevally, TP

Table 2. Diel and seasonal changes in swimming depth and body temperature for giant trevally Caranx ignobilis (U) and Galapagos sharks Carcharhinus galapagensis (G) at Pearl and Hermes Atoll. TL: total length. Results were obtained from generalized additive models, with an included autocorrelation function. Temperature and depth were analyzed over the diel cycle and monthly. Months with significant values are given. All values in bold are significantly different

\begin{tabular}{|c|c|c|c|c|c|c|c|c|c|c|}
\hline & \multirow{3}{*}{$\begin{array}{c}\mathrm{TL} \\
(\mathrm{cm})\end{array}$} & \multirow[t]{3}{*}{ Sex } & \multicolumn{4}{|c|}{ Swimming depth } & & & \multicolumn{2}{|c|}{ Body temp. } \\
\hline & & & 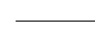 & Diel- & $-\mathrm{Se}$ & son- & & iel- & Mont & \\
\hline & & & $t$ & $\mathrm{p}$ & $\begin{array}{l}\text { Range of } \\
\text { p-values }\end{array}$ & $\begin{array}{l}\text { Month } \\
\text { signif. }\end{array}$ & F & $\mathrm{p}$ & $\begin{array}{l}\text { Range of } \\
\text { p-values }\end{array}$ & $\begin{array}{l}\text { Month } \\
\text { signif. }\end{array}$ \\
\hline U1 & 92 & - & 4.26 & $<0.00001$ & $<\mathbf{0 . 0 0 0 0 1 - 0 . 9 6}$ & May, June & 2.46 & 0.001 & $<0.00001-0.003$ & All \\
\hline $\mathrm{U} 2$ & 109 & - & 5.52 & $<0.0001$ & $<\mathbf{0 . 0 0 0 0 1 - 0 . 8 9}$ & March-June & 8.64 & $<0.0001$ & $<\mathbf{0 . 0 0 0 0 1 - 0 . 3 7}$ & May-Dec \\
\hline U3 & 89 & - & 22.83 & $<0.0001$ & $<\mathbf{0 . 0 0 0 0 1 - 0 . 6 4}$ & May-October & 12.75 & $<0.0001$ & $<\mathbf{0 . 0 0 0 1 - 0 . 8 8}$ & May-Nov \\
\hline U4 & 101 & - & 0 & 0.93 & $\mathbf{0 . 0 0 2}-0.74$ & April-July & 5.63 & $<0.0001$ & $<\mathbf{0 . 0 0 0 0 1 - 0 . 2 3 ~}$ & May-Dec \\
\hline G1 & 148 & F & -2.69 & 0.008 & $0.09-0.93$ & None & 2.23 & 0.001 & $<\mathbf{0 . 0 0 0 0 1 - 0 . 7 8}$ & May-Dec \\
\hline $\mathrm{G} 2$ & 168 & $M$ & -3.72 & 0.0002 & $\mathbf{0 . 0 0 0 3}-0.10$ & October & 0 & 0.07 & $<\mathbf{0 . 0 0 0 0 1}-0.75$ & May-Dec \\
\hline G3 & 199 & $\mathrm{M}$ & -5.95 & $<0.00001$ & $<\mathbf{0 . 0 0 0 0 1 - 0 . 9 2}$ & May, June & 21.58 & $<0.0001$ & $<\mathbf{0 . 0 0 0 0 1 - 0 . 4 8}$ & May-Dec \\
\hline
\end{tabular}



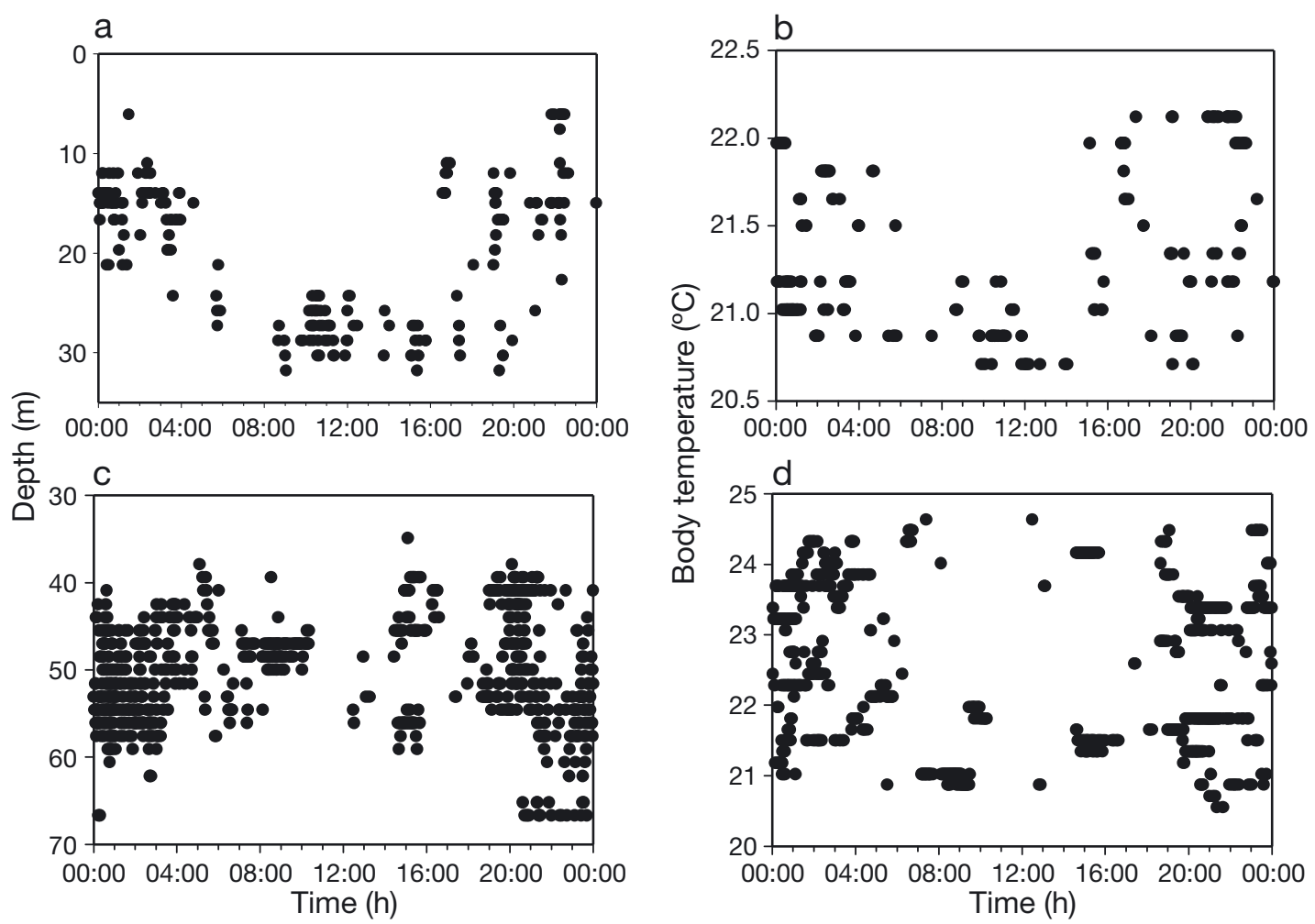

Fig. 5. Diel changes in depth and body temperature for giant trevally Caranx ignobilis (a,b) U1 and (c,d) U3 at Pearl and Hermes Atoll. Behaviors include (a) regular diel vertical migrations and (c) reverse diel migrations. Data were obtained using passive acoustic transmitters from December to May. Note the use of different scales on the $y$-axes. Gaps in data indicate periods where there were no acoustic detections
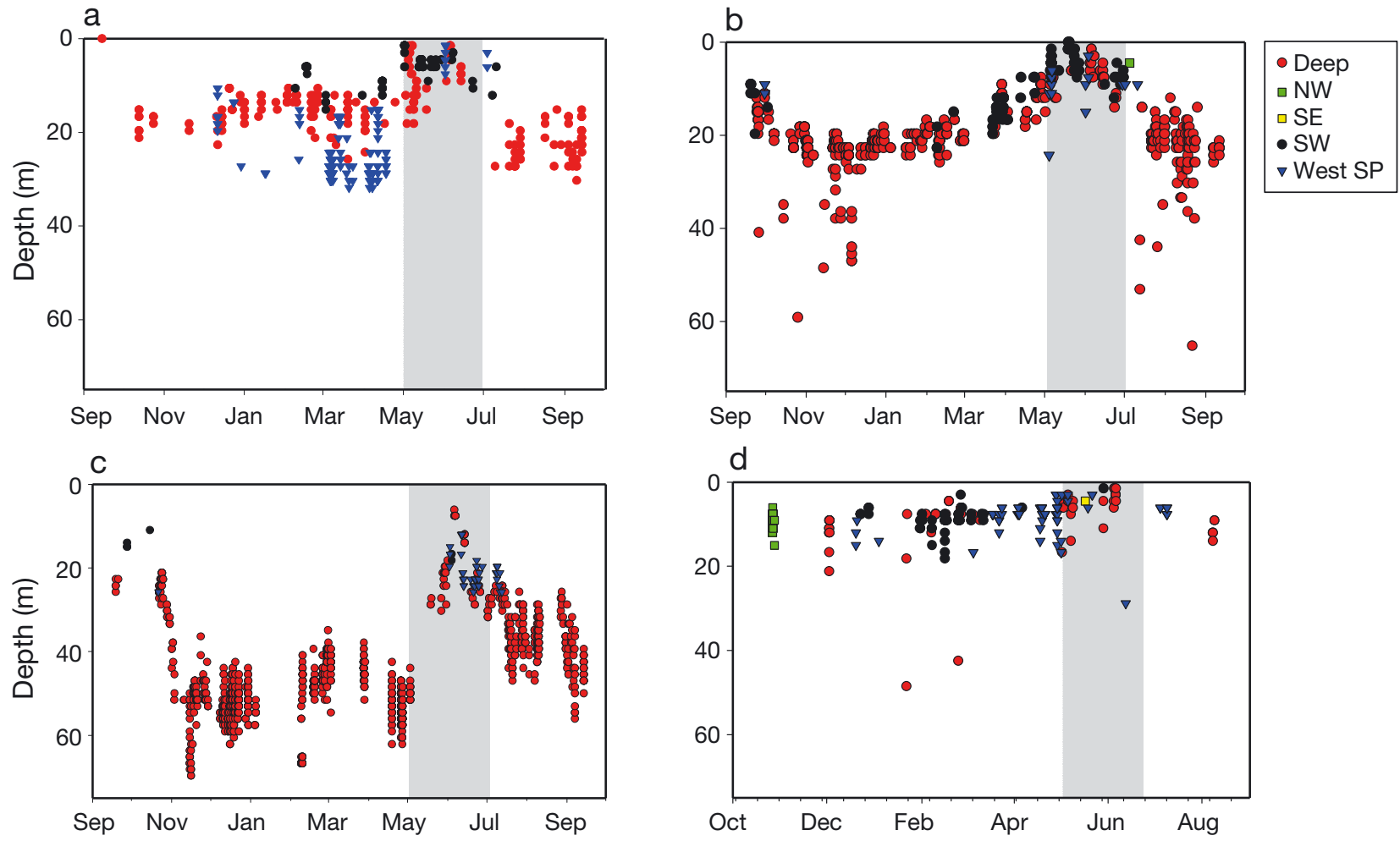

Fig. 6. Seasonal changes in swimming depth for giant trevally Caranx ignobilis at Pearl and Hermes Atoll. Each location is color coded to identify the receiver where detections were made. The grey column represents the known spawning period for this species. Data are for (a-d) individuals U1 to U4. See Fig. 1 for locations of the receivers and definition of abbreviations 

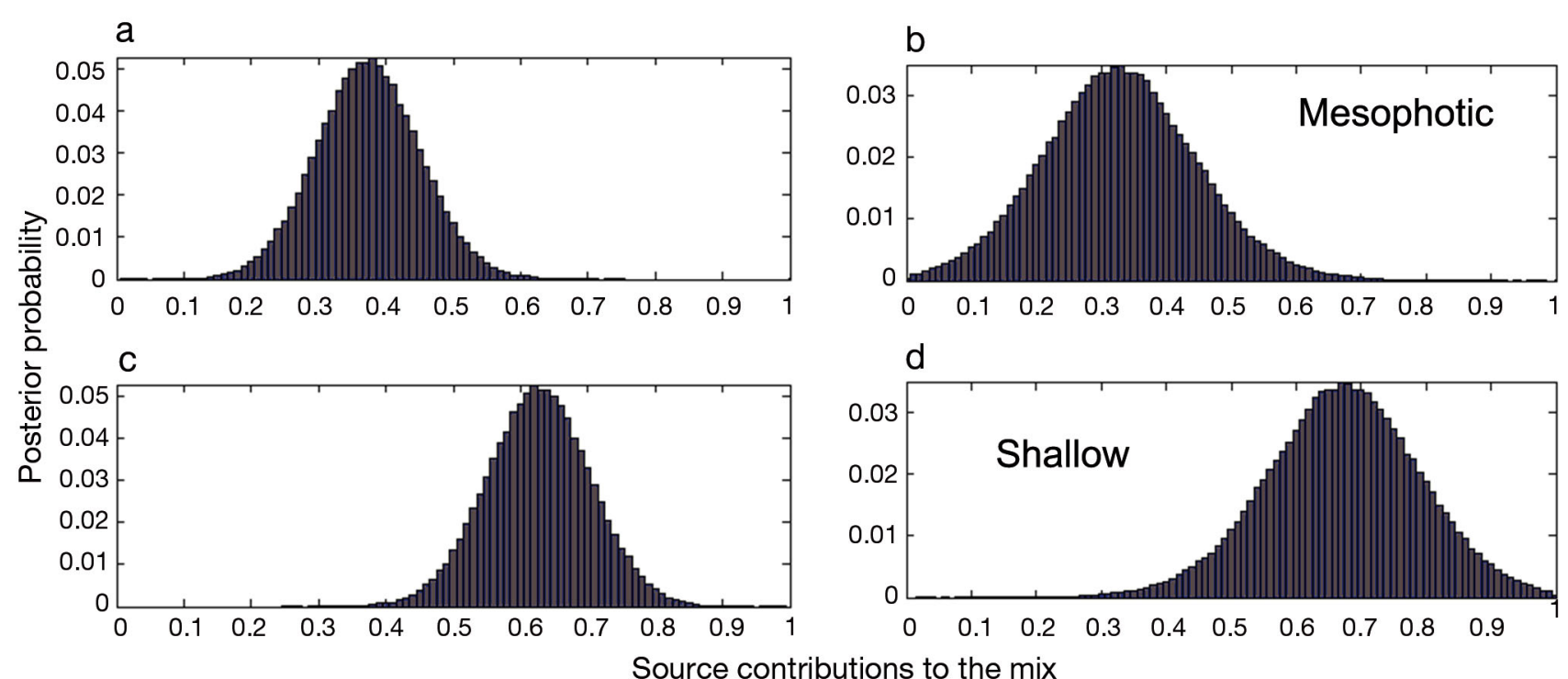

Fig. 7. Mixing model results using $\delta^{15} \mathrm{~N}$ and $\delta^{13} \mathrm{C}$ values for $(\mathrm{a}, \mathrm{c})$ giant trevally Caranx ignobilis and (b,d) Galapagos sharks Carcharhinus galapagensis. Model results present probability distributions of the proportional contribution of prey from either $(\mathrm{a}, \mathrm{b})$ mesophotic $(>55 \mathrm{~m})$ or $(\mathrm{c}, \mathrm{d})$ shallow $(<30 \mathrm{~m})$ reefs

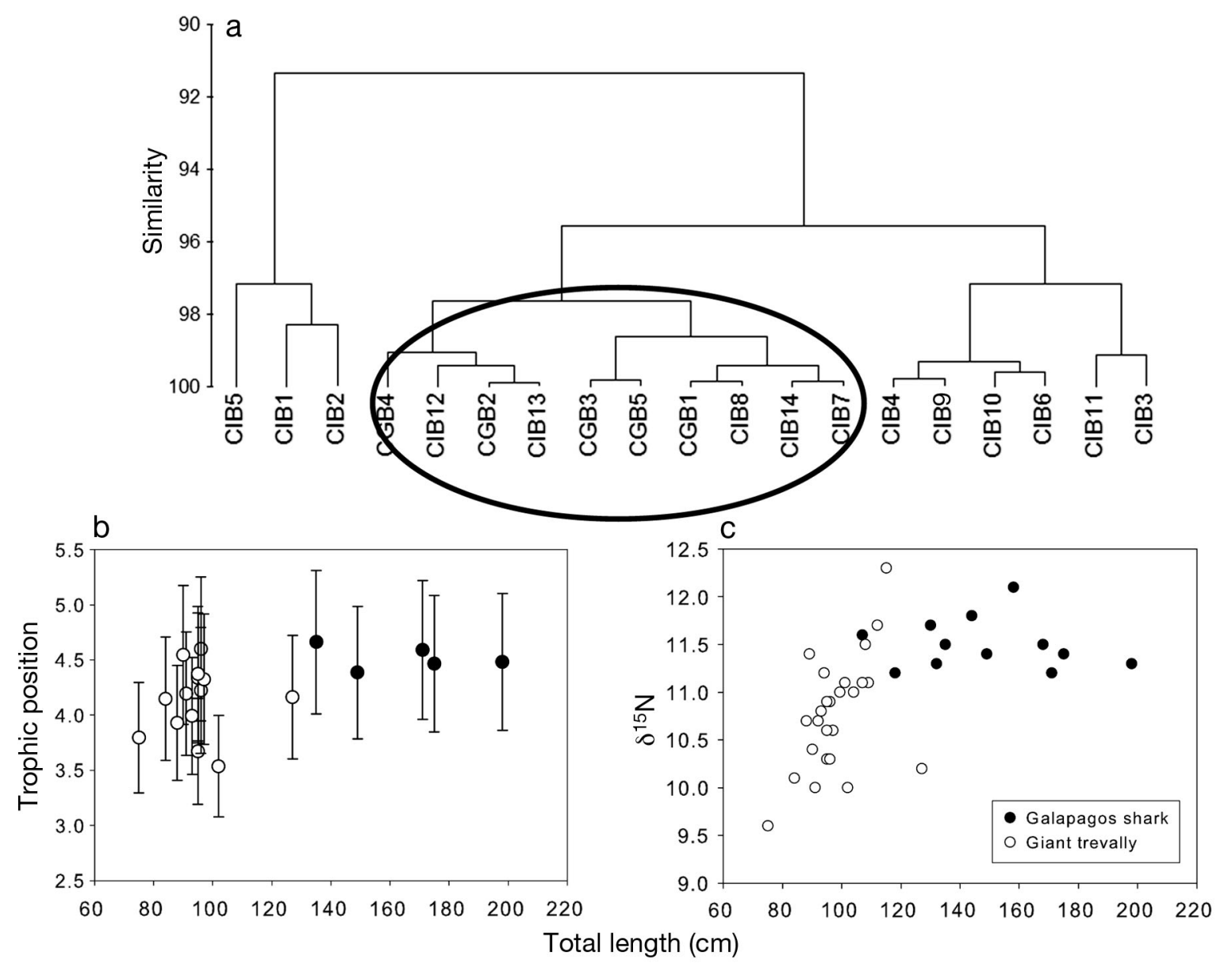

Fig. 8. Top predator trophic positions (TP) as determined from the difference in $\delta^{15} \mathrm{~N}$ values of glutamic acid and phenylalanine at Pearl and Hermes Atoll. (a) Cluster analysis of Galapagos sharks Carcharhinus galapagensis (CGB) and giant trevally Caranx ignobilis (CIB) TPs, demonstrating that sharks and a group of giant trevally occupy similar trophic positions. (b) The range in TP is not related to fish size. (c) Bulk tissue $\delta^{15} \mathrm{~N}$ values are not related to fish size for sharks, but are for giant trevally 
ranged from 3.5 to 4.6 (Fig. 8). Cluster analysis revealed that 5 trevally were grouped with Galapagos sharks based on their TP, while the remaining trevally formed separate groups of animals with lower TPs (Fig. 8). The range of TPs in trevally was not related to fish size $(F=0.08, \mathrm{p}=0.79)$. Using the groups generated from the cluster analysis (based on TP) we compared the $\delta^{15} \mathrm{~N}$ values of phenylalanine between sharks, high-TP giant trevally, low-TP trevally, and 4 individual milletseed butterfly fish. There were significant differences (1-way ANOVA, $F$ $=10.11, \mathrm{p}<0.0001, \mathrm{df}=22$ ), mainly due to the ${ }^{15} \mathrm{~N}$ enrichment in phenylalanine in the trevally feeding at lower TPs $(1.28 \pm 0.80 \%)$ compared to Galapagos sharks $(-0.45 \pm 0.39)$ and high-TP trevally $(-0.46 \pm$ $0.66 \%$ ). Butterflyfish did not differ significantly from any group, but the $\delta^{15} \mathrm{~N}$ values of phenylalanine were closer in range to the lower-TP trevally $(0.67 \pm$ $0.76 \%$ ). There was no significant effect of species $(F$ $=1.2, \mathrm{p}=0.3)$ or TL $(F=0, \mathrm{p}=1.0)$ on TP.

\section{DISCUSSION}

Marine predators at P\&H use MCEs over diel and seasonal time frames, although there is inter- and intra-specific variability in the extent of this use. Galapagos sharks performed reverse diel vertical movements at times, diving near the bottom of the $\mathrm{MCE}$ at night (50 to $70 \mathrm{~m}$ ) and moving into shallower water during the day. The deeper dives during the night lead to cooler body temperatures during this period. Sharks may be employing a 'hunt warm, rest cool' strategy where they rest in cooler waters, lowering metabolic rates and minimizing energy expenditure (Sims et al. 2006). Giant trevally showed more variability in vertical behavior, with some individuals performing regular diel vertical movements, while others behaved similarly to sharks and performed reverse diel movements. There were also diel differences in trevally body temperature, but for some individuals these changes were small and within the range of error of the V16PT sensors. The error should be consistent throughout the time series (i.e. absolute temperature may vary, but relative differences should be genuine) but any interpretation of behavioral thermoregulation should be treated cautiously. All animals showed periods of horizontal diel movements to and from the MCE which tended to match the patterns of vertical movements (i.e. sharks on the MCE at night, while trevally were a mix, with some individuals there during the day and some at night). Visual observations support these conclusions, as sharks were rarely seen during daytime dives on the MCE, but frequently seen at the shallower sites (Y. P. Papastamatiou pers. obs.).

Although there was individual variability, most predators demonstrated seasonal movements with either greater use of the MCE themselves, or shallower water in general. This was particularly pronounced in trevally, where all individuals used shallower waters (even if remaining over the MCE) from May to July and deeper water from January to March. Seasonal movements into shallow water in May correspond with the period when body temperatures start to increase and also coincide with the period of spawning behavior in giant trevally (Sudekum et al. 1991, Meyer et al. 2007). It is possible that increasing body temperatures may play an important role in stimulating spawning behavior in this species. Galapagos sharks also showed seasonal changes in horizontal and vertical movements, with individuals occupying deeper waters and the MCE from September to December (summer to fall), which also corresponded to periods of higher body temperatures. However, all tagged individuals were immature so these movements are not related to mating (Wetherbee et al. 1996). It is possible that sharks use the MCEs to access cooler water during the warmer summer/fall periods.

While the telemetry data suggests that the MCE is a habitat used by sharks and trevally, results of stable isotope analysis suggest that predators are obtaining a greater proportion of their prey from shallow reefs, with a smaller proportion coming from the MCE. MCE fish communities at $\mathrm{P} \& \mathrm{H}$ are very different from shallow water counterparts, with more zooplanktivores, and fewer herbivores and secondary carnivores on the MCEs (Kane et al. 2014, Supplement 11, Fig. S9 at www.int-res.com/articles/suppl/ m521p155_supp.pdf). The overall MCE community tends to have lower $\delta^{13} \mathrm{C}$ values compared with the shallow community (suggesting a more planktonbased food web), while the predators get the majority of their carbon from benthic algae-based food webs (Hilting et al. 2013, present study). While we certainly did not sample all potential prey items on the $\mathrm{MCE}$, we did manage to sample representatives of most of the abundant fishes $>10 \mathrm{~cm}$. Furthermore, when detected on the MCE, most dives performed by predators were shallower than $60 \mathrm{~m}$, even though the majority of reef fish biomass is present at depths $>60$ m (Y. P. Papastamatiou pers. obs., R. K. Kosaki unpubl. data). Some of the trevally rarely went below $30 \mathrm{~m}$ when detected on the MCE receiver, which means they were up in the water column. Again, 
accuracy of depth sensors means it is possible that predators were deeper (or shallower) than the recorded values.

Sharks caught over MCEs are tertiary predators, while trevally appear to occupy a range of TPs. Some individual trevally (occupying higher TPs) forage similarly to Galapagos sharks, while others forage in areas, or on prey, that give them a lower TP. One possibility is that lower TP trevally are consuming the mackerel scad Decapterus macarellus, a pelagic zooplanktivore, while other trevally are feeding on shallow reef fishes of higher TP (Sudekum et al. 1991). Numerous studies are starting to show individual specialization in diet and behavior of marine predators, which may reduce inter- and intra-specific competition (e.g. Matich et al. 2011). There is likely to be strong competition between and within Galapagos sharks and at least a proportion of giant trevally, especially at $\mathrm{P} \& \mathrm{H}$ where predator numbers are high (Sudekum et al. 1991, Papastamatiou et al. 2006). Further evidence for this is provided by the fine-scale spatial and temporal partitioning between sharks and giant trevally, in relation to the amount of time they spent in different habitats, and the phase shifts between the 2 species in terms of seasonal utilization of MCEs.

Our study also suggests that sharks and trevally may be significant transporters of nutrients from shallow habitats to MCEs, but to a lesser degree in the opposite direction. Diel horizontal and vertical movements between deep and shallow reefs have also been suggested for reef sharks associated with an atoll in Belize, although it was not possible to directly associate vertical movements with particular habitats or determine the direction of nutrient transfer (Chapman et al. 2007). A shark feeding in shallow habitats and performing diel movements (or at least within $110 \mathrm{~h}$ ) to the MCE will contribute both fecal and urinary sources of organic material, carbon, nitrogen and other nutrients. Sharks have absorption efficiencies of approximately 70 to $86 \%$ for organic material (Wetherbee \& Gruber 1993). No data on organic carbon absorption efficiencies exists for sharks, but a carnivorous teleost (trout) had approximate efficiencies of $36 \%$ (Penczak et al. 1982). Based on length-weight regressions, the sharks we caught weighed 19 to $100 \mathrm{~kg}$ (Wetherbee et al. 1996). Assuming they are consuming $2 \%$ body weight per day, with $65 \%$ of the diet coming from shallow reefs, and $50 \%$ of fecal production occurring over the MCE, then each shark may be transporting between 0.02 and $0.09 \mathrm{~kg} \mathrm{~d}^{-1}$ of organic material and 0.006 and $0.03 \mathrm{~kg} \mathrm{C} \mathrm{d}^{-1}$, from shallow habitats to MCEs, at least during the summer and fall months. Mobile predators could be a significant source of particulate organic matter to MCEs compared to estimated input rates via other nutrient cycling processes at other tropical ecosystems, particularly for exposed forereef habitats (e.g. Max et al. 2013). Of course, this is a very crude estimate and we do not know how many sharks use the atoll or how much time they spend on the MCE, and we only tracked sharks caught over the $\mathrm{MCE}_{\text {; }}$ hence habitat use will be biased towards those individuals. There may be many individuals that never use the MCE. Furthermore, we do not know where egestion and excretion occurs, although it is highly likely that at least some occurs over MCE habitats.

There are several caveats with both our telemetry and isotope results. Telemetry results are based on small sample sizes and low acoustic coverage, hence use of MCE habitats is likely greatly underestimated. We only had 7 receivers for the whole atoll, and only one of those was in an MCE habitat. Network analysis only identifies edges between the locations of receivers, and other areas may be more closely linked by predator movements. However, our study represents a minimum estimate of MCE habitat use, and still identified diel and seasonal movements. Using carbon and nitrogen isotopic compositions to infer fine spatial scale locations of foraging also requires assumptions. Shark muscle has isotope turnover rates of months to a year, hence the isotopic compositions of muscle represent feeding activity over a similar time frame (Hussey et al. 2012). In addition, sharks retain urea and trimethyl amine oxide in their tissues, which means that the dynamics of isotope incorporation may differ between sharks and teleosts (Dale et al. 2011, Hussey et al. 2012). In particular, results comparing isotopic signatures between sharks and trevally should be treated cautiously, as muscle turnover times may vary. However, a recent study found that bluefin tuna Thunnus orientalis (an endothermic fish) had similar tissue turnover times to ectothermic leopard sharks (Madigan et al. 2012). Trevally are not endothermic, and are likely to have tissue turnover times similar to or longer than bluefin tuna (due to their lower metabolic rates). Therefore, it seems unlikely that differences in tissue turnover times influenced the wide range of trophic positions occupied by trevally relative to sharks. Finally, we had small sample sizes for stable isotope analyses, especially for prey on MCEs. However, the different community structure found on the MCE and the vertical habitat use of predators add additional support to our hypothesis (Kane et al. 2014). 
The combination of telemetry and isotopic compositions allows us to reveal the potential roles of MCEs for marine predators, and how these vary seasonally as well as between and within species. We show that top predators have at least the potential to add significant contributions of organic carbon to MCEs relative to other sources of nutrient cycling. A growing number of studies are considering the potential role marine predators may have in linking ecological habitats (e.g. Matich et al. 2011, McCauley et al. 2012, Ketchum et al. 2014), and the combination of telemetry and stable isotope analysis will allow greater refinement in predicting the direction and magnitude of nutrient transport between habitats.

Acknowledgements. We thank the crew of the NOAA research vessel 'Hi'ialakai' for supporting all field work in the NWHI. For assistance and support with technical diving, we also thank K. Gleason, G. McFall, J. Leonard, B. Hauk, K. Lopes, and J. Copus. Assistance with predator tagging/fish collecting was also provided by C. Clark, R. Pyle, J. Anderson, and D. Wagner. We thank D. Bradley for help with statistical analysis, and D. Jacoby for discussions regarding network analysis. Research was conducted under the University of Florida Animal Care Protocol \# 201105813. Funding was provided by the National Geographic Committee for Research \& Exploration (grant \# 8951-11) and by the National Science Foundation grant OCE-1041329 (to B.N.P. and Jeffrey C. Drazen). Any opinions, findings, and conclusions or recommendations expressed in this material are those of the author(s) and do not necessarily reflect the views of the National Science Foundation. This work received funding from the MASTS (The Marine Alliance for Science and Technology for Scotland) pooling initiative and their support is gratefully acknowledged. MASTS is funded by the Scottish Funding Council (grant reference HR09011) and contributing institutions. This is SOEST contribution number 9238.

\section{LITERATURE CITED}

Andrews KS, Williams GD, Farrer D, Tolimieri N, Harvey CJ, Bargmann G, Levin PS (2009) Diel activity patterns of sixgill sharks, Hexanchus griseus: the ups and downs of an apex predator. Anim Behav 78:525-536

> Blum JD, Popp BN, Drazen JC, Choy CA, Johnson MW (2013) Methylmercury production below the mixed layer of the North Pacific Ocean. Nat Geosci 6:879-884

Bongaerts P, Ridgway T, Sampayo EM, Hoegh-Guldberg O (2010) Assessing the 'deep reef refugia' hypothesis: focus on Caribbean reefs. Coral Reefs 29:309-327

Carlisle AB, Kim SL, Semmens BX, Madigan DJ and others (2012) Using stable isotope analysis to understand the migration and trophic ecology of northeastern Pacific white sharks (Carcharodon carcharias). PLoS ONE 7: e30492

Caut S, Angulo E, Courchamp F (2009) Variation in discrimination factors $\left(\Delta^{15} \mathrm{~N}\right.$ and $\left.\Delta^{13} \mathrm{C}\right)$ : the effect of diet isotopic values and applications for diet reconstruction. J Appl Ecol 46:443-453
Chapman DD, Pikitch EK, Babcock EA, Shivji MS (2007) Deep-diving and diel changes in vertical habitat use by Caribbean reef sharks Carcharhinus perezi. Mar Ecol Prog Ser 344:271-275

Chikaraishi Y, Ogawa NO, Kashiyama Y, Takano Y and others (2009) Determination of aquatic food-web structure based on compound-specific nitrogen isotopic composition of amino acids. Limnol Oceanogr Methods 7:740-775

> Dale JJ, Wallsgrove NJ, Popp BN, Holland KN (2011) Nursery habitat use and foraging ecology of the brown stingray Dasyatis lata determined from stomach contents, bulk and amino acid stable isotopes. Mar Ecol Prog Ser 433:221-236

Fry B, Baltz DM, Benfield C, Fleeger JW, Gace A, Hass HL, Quinones-Rivera Z (2003) Stable isotope indicators of movement and residency for brown shrimp (Farfantepenaeus aztecus) in coastal Louisiana marshscapes. Estuaries 26:82-97

> Geesey GG, Alexander GV, Bray RN, Miller AC (1984) Fish fecal pellets are a source of minerals for inshore reef communities. Mar Ecol Prog Ser 15:19-25

Hanneman RA, Riddle M (2005) Introduction to social network methods. University of California Riverside, Riverside, CA

> Hannides CCS, Popp BN, Choy CA, Drazen JC (2013) Midwater zooplankton and suspended particle dynamics in the North Pacific Subtropical Gyre: a stable isotope perspective. Limnol Oceanogr 58:1931-1946

Hilting AK, Currin CA, Kosaki RK (2013) Evidence for benthic primary production support of an apex predatordominated coral reef food web. Mar Biol 160:1681-1695

> Hussey NE, Brush J, McCarthy ID, Fisk AT (2010) $\delta^{15} \mathrm{~N}$ and $\delta^{13} \mathrm{C}$ diet-tissue discrimination factors for large sharks under semi-controlled conditions. Comp Biochem Physiol A 155:445-453

Hussey NE, MacNeil MA, Olin JA, McMeans BC, Kinney MJ, Chapman DD, Fisk AT (2012) Stable isotopes and elasmobranchs: tissue types, methods, applications and assumptions. J Fish Biol 80:1449-1484

> Jacoby DMP, Brooks EJ, Croft DP, Sims DW (2012) Developing a deeper understanding of animal movements and spatial dynamics through novel application of network analyses. Methods Ecol Evol 3:574-583

Kahng SE, Copus JM, Wagner D (2014) Recent advances in the ecology of mesophotic coral ecosystems (MCE). Curr Opin Environ Sust 7:72-81

> Kane C, Kosaki RK, Wagner D (2014) High levels of mesophotic reef fish endemism in the Northwestern Hawaiian Islands. Bull Mar Sci 90:693-703

> Ketchum JT, Hearn A, Klimley AP, Penaherrera C and others (2014) Inter-island movements of scalloped hammerhead sharks (Sphyrna lewini) and seasonal connectivity in a marine protected area of the eastern tropical Pacific. Mar Biol 161:939-951

> Kim SL, Koch PL (2012) Methods to collect, preserve, and prepare elasmobranch tissues for stable isotope analysis. Environ Biol Fishes 95:53-63

Klimley AP, Nelson DP (1984) Diel movement patterns of scalloped hammerhead sharks (Sphyrna lewini) in relation to El Bajo Espiritu Santo: a refuging central-position social system. Behav Ecol Sociobiol 15:45-54

Lorrain A, Graham BS, Popp BN, Allain V and others (2014) Nitrogen isotopic baselines and implications for estimating foraging habitat and trophic position of yellowfin tuna in the Indian and Pacific Oceans. Deep-Sea Res 
Part II (in press), doi:10.1016/j.dsr2.2014.02.003

Lundberg J, Moberg F (2003) Mobile link organisms and ecosystem functioning: implications for ecosystem resilience and management. Ecosystems 6:87-98

- Madigan DJ, Litvin SY, Popp BN, Carlisle AB, Farwell CJ, Block BA (2012) Tissue turnover rates and isotopic trophic discrimination factors in the endothermic teleost, Pacific bluefin tuna (Thunnus orientalis). PLoS ONE 7: e49220

> Maraun D, Kurths J, Holschneider M (2007) Non-stationary Gaussian processes in wavelet domain: Synthesis, estimation, and significance testing. Phys Rev E 75: 016707-016714

Matich P, Heithaus MR, Layman CA (2011) Contrasting patterns of individual specialization and trophic coupling in two marine apex predators. J Anim Ecol 80:294-305

Max LM, Hamilton SL, Gaines SD, Warner RR (2013) Benthic processes and overlying fish assemblages drive the composition of benthic detritus on a central Pacific coral reef. Mar Ecol Prog Ser 482:181-195

McCauley DJ, Young HS, Dunbar RB, Estes JA, Semmens BX, Micheli F (2012) Assessing the effects of large mobile predators on ecosystem connectivity. Ecol Appl 22:1711-1717

> Meyer JL, Schultz ET (1985) Migrating haemulid fishes as a source of nutrients and organic matter on coral reefs. Limnol Oceanogr 30:146-156

> Meyer CG, Holland KN, Papastamatiou YP (2007) Seasonal and diel movements of giant trevally Caranx ignobilis at remote Hawaiian atolls: implications for the design of Marine Protected Areas. Mar Ecol Prog Ser 333:13-25

> Meyer CG, Papastamatiou YP, Holland KN (2010) A multiple instrument approach to quantifying the movement patterns and habitat use of tiger (Galeocerdo cuvier) and Galapagos sharks (Carcharhinus galapagensis) at French Frigate Shoals, Hawaii. Mar Biol 157:1857-1868

Moore JW, Semmens BX (2008) Incorporating uncertainty and prior information into stable isotope mixing models. Ecol Lett 11:470-480

Papastamatiou YP, Wetherbee BM, Lowe CG, Crow GL (2006) Distribution and diet of four species of carcharhinid shark in the Hawaiian Islands: evidence for resource partitioning and competitive exclusion. Mar Ecol Prog Ser 320:239-251

Papastamatiou YP, Friedlander AM, Caselle JE, Lowe CG (2010) Long-term movement patterns and trophic ecology of blacktip reef sharks (Carcharhinus melanopterus) at Palmyra Atoll. J Exp Mar Biol Ecol 386:94-102

Penczak T, Galicka W, Molinski M, Kusto E, Zalewski M (1982) The enrichment of a mesotrophic lake by carbon, phosphorous and nitrogen from the cage aquaculture of

Editorial responsibility: Nicholas Tolimieri,

Seattle, Washington, USA rainbow trout Salmo gairdneri. J Appl Ecol 19:371-393

Popp BN, Graham BS, Olson RJ, Hannides CCS and others (2007) Insight into the trophic ecology of yellowfin tuna, Thunnus albacares, from compound-specific nitrogen isotope analysis of protenaceous amino acids. In: Dawson T, Siegwolf R (eds) Stable isotopes as indicators of ecological change. Terrestrial Ecology Series, Elsevier Academic Press, Amsterdam, p 173-190

> Post DM (2002) Using stable isotopes to estimate trophic position: models, methods, and assumptions. Ecology 83: 703-718

R Development Core Team (2013) R: A language and environment for statistical computing. R Foundation for Statistical Computing, Vienna. www.R-project.org/

Riotte-Lambert L, Benhamou S, Chamaille-Jammes S (2013) Periodicity analysis of movement recursions. J Theor Biol 317:238-243

Schmitz OJ, Halena D, Trussell GC (2010) Predator control of ecosystem nutrient dynamics. Ecol Lett 13:1199-1209

> Simpfendorfer CA, Heupel MR, Collins AB (2008) Variation in the performance of acoustic receivers and its implication for positioning algorithms in a riverine setting. Can J Fish Aquat Sci 65:482-492

Sims DW, Southall EJ, Tarling GA, Metcalfe JD (2005) Habitat-specific normal and reverse diel vertical migration in the plankton-feeding basking shark. J Anim Ecol 74: 755-761

Sims DW, Wearmouth VJ, Southall EJ, Hill JM and others (2006) Hunt warm, rest cool: bioenergetic strategy underlying diel vertical migration of a benthic shark. J Anim Ecol 75:176-190

Slattery M, Lesser MP, Brazeau D, Stokes MD, Leichter JJ (2011) Connectivity and stability of mesophotic coral reefs. J Exp Mar Biol Ecol 408:32-41

Sudekum AE, Parrish JD, Radtke RL, Ralston S (1991) Life history and ecology of large jacks in undisturbed, shallow, oceanic communities. Fish Bull 89:493-513

> Wetherbee BM, Gruber SH (1990) The effects of ration level on food retention time in juvenile lemon sharks, Negaprion brevirostris. Environ Biol Fishes 29:59-65

Wetherbee BM, Gruber SH (1993) Absorption efficiency of the lemon shark Negaprion brevirostris at varying rates of energy intake. Copeia 2:416-425

Wetherbee BM, Crow GL, Lowe CG (1996) Biology of the Galapagos shark, Carcharhinus galapagensis, in Hawaii. Environ Biol Fishes 45:299-310

Whitehead H (2009) SOCPROG programs: analyzing animal social structures. Behav Ecol Sociobiol 63:765-778

Wood SN (2006) Generalized additive models. An introduction with R. Chapman and Hall/CRC Press, Boca Raton, FL

Submitted: July 18, 2014; Accepted: November 6, 2014 Proofs received from author(s): January 27, 2015 